\title{
PHYSICAL MAP OF A YAC CONTIG CONTAINING THE REGION OF THE HUMAN GENE (HYRC) COMPLEMENTING HYPER-RADIOSENSITIVITY OF THE SCID MOUSE MUTATION
}

\author{
Yoriko Watanabe, ${ }^{1,2, *}$ Naomichi Matsumoto, ${ }^{1}$ Tohru OHTA, ${ }^{1}$ \\ Takahiro TsuJITA, ${ }^{1}$ and Norio NIIKAWA ${ }^{1}$ \\ ${ }^{1}$ Department of Human Genetics, Nagasaki University School of Medicine, \\ 1-12-4 Sakamoto, Nagasaki 852, Japan \\ ${ }^{2}$ Department of Pediatrics, Kurume University School of Medicine, \\ 67 Asahi-machi, Kurume, Fukuoka 830, Japan
}

\begin{abstract}
Summary We previously mapped the putative human $H Y R C$ (the hyper-radiosensitivity of the scid mutation, complementing gene) to human chromosome 8q11.1 by fluorescence in situ hybridization (FISH) using Alu-based PCR products from a mouse-human scid radiation cell hybrid (RD15/5) as probes. From a cosmid library constructed from RD15/5, 57 cosmid clones containing human DNA inserts were isolated, 18 of which were mapped to $8 \mathrm{q} 11$. Based on the sequences of plasmid subclones of the 18 cosmids, five novel sequence-tagged-sites (STSs) were made. By a screening of the CEPH-YAC library with these STSs, five yeast artificial chromosome (YAC) clones were isolated. All these YAC clones were confirmed not to be chimeric by FISH, but two of them showed deleted human insert DNAs. Using the other 3 non-deleted YACs, we constructed a physical map covering the $H Y R C$ region. We confirmed that the recently isolated gene (the DNA-PK $\mathrm{DS}_{\mathrm{cs}}$ gene) which is a strong candidate for $H Y R C$ is located within the present contig and spans less than $200 \mathrm{~kb}$. This map will be useful for the analysis of the genomic structure of the DNA-PK complementing genes in the HYRC region.
\end{abstract}

Key Words scid, HYRC gene, DNA-PK ${ }_{c s}$ gene, STS, physical map

\section{INTRODUCTION}

Murine severe combined immunodeficiency (scid) is an autosomal recessive disorder characterized by a lack of functional $B$ and $T$ lymphocytes due to a failure of $\mathrm{V}(\mathrm{D}) \mathbf{J}$ recombination activity that normally mediates somatic assembly of both

Received October 6, 1995; Revised version accepted December 16, 1995.

${ }^{*}$ To whom correspondence should be addressed. 
immunoglobulin and T-cell receptor gene elements (Bosma et al., 1983). Investigation of $V(D) J$ recombination in the scid mouse has shown that the immune system gene elements are not correctly rejoined in the coding sequences during V(D)J recombination, because of an aberrant recombinase (Lieber, 1992). Hence, the scid gene (scid) is considered to encode a key enzyme involving $\mathrm{V}(\mathrm{D}) \mathrm{J}$ recombination. Moreover, illegitimate rejoining of DNA double-strand breaks in scid cells also gives rise to a marked increase in sensitivity to ionizing radiation (Fulop and Phillips, 1990; Biedermann et al., 1991; Hendrickson et al., 1991). We previously mapped the putative human gene $(H Y R C)$ for hyper-radiation sensitivity that is complementary to the murine scid to human chromosome $8 \mathrm{q} 11.1$ by fluorescence in situ hybridization (FISH) using Alu-PCR products from human-scid mouse radiation cell hybrids as probes (Komatsu et al., 1993). A strong candidate gene (the DNA-PK $\mathrm{cs}$ gene) for $H Y R C$ has been identified and mapped to the same human chromosomal region (Kirchgessner et al., 1995; Blunt et al., 1995; LeesMiller et al., 1995), and its partial cDNA has been cloned (Blunt et al., 1995).

We also previously constructed a cell line (RD15/5), a tertiary radiation hybrid cell clone, by repetition of irradiation. Since the cell line contains smaller human DNA fragments that include $H Y R C$ than its parent hybrid, it was considered as a good source to make a physical map useful for positional cloning of $H Y R C$. We report here a cosmid library construction of the human DNA inserted in RD15/5 and isolation of cosmid clones, sequence tagged sites (STSs), their corresponding yeast artificial chromosome (YAC) clones and a physical map of the YAC contig.

\section{MATERIALS AND METHODS}

Cosmid isolation and FISH analysis. A cosmid library in pWEX15 was constructed from the DNA of a human-mouse scid radiation hybrid cell line, RD15/5, that contained only human chromosome 8q11-q12 DNA in mouse DNA background. Cosmid clones containing human DNA inserts were selected by colony hybridization at $55^{\circ} \mathrm{C}$ using total human genomic DNA as a pool of probes. To exclude clones with only mouse DNA, another screening was performed by dot-blot hybridization first using total human DNA and subsequently using total mouse DNA as probes. After hybridization at $65^{\circ} \mathrm{C}$, dot-blotted filters were washed at $55^{\circ} \mathrm{C}$ in $0.1 \times \mathrm{SSC} / 0.1 \% \mathrm{SDS}$. Clones with negative or weak signals by the second dot-blot hybridization were subjected to FISH in order to confirm their localization to human chromosome 8. Cosmid DNAs labeled with biotin-16dUTP (Boehringer-Mannheim, Germany) by nick translation were hybridized to human metaphase chromosomes, as described previously (Deng et al., 1992).

Isolation of STSs and YACs from cosmid clones. The DNA of cosmid clones mapped to $8 \mathrm{q} 11$ or hybridized diversely to human chromosomes by FISH was digested with Sau3AI and subcloned into pUC19. Colony hybridization was 
carried out using total human DNA as probes under the same hybridization/ washing conditions as those for cosmid isolation. With an aim to exclude highly repetitive human DNA sequences, 10 to 20 plasmid clones with negative signals were selected from each cosmid and used as probes for Southern blot hybridization to EcoRI-digested total human genomic DNA, EcoRI-digested DNA from mousehuman hybrid cells (A9Neo8) containing chromosome 8 as only human origin and to EcoRI-cut total scid mouse (SC3VA4) genomic DNA. After hybridization at $65^{\circ} \mathrm{C}$, membranes were washed at $65^{\circ} \mathrm{C}$ in $0.1 \times \mathrm{SSC} / 0.1 \% \mathrm{SDS}$. Plasmid clones showing unique electrophoretic bands for only human and A9Neo8 DNA underwent base-sequencing by means of an autosequencer (Pharmacia, Sweden). Sets of oligonucleotide primers were designed for STSs on the basis of the sequences, and polymerase chain reaction (PCR) was performed for 30 cycles with denaturation at $94^{\circ} \mathrm{C}$ for $1 \mathrm{~min}$, annealing at $55-60^{\circ} \mathrm{C}$ for $1 \mathrm{~min}$ and extension at $72^{\circ} \mathrm{C}$ for 1.5 min. Using these STS primers, the CEPH (the Centre d'Etude de Polymorphisme Humaine, France) YAC library was screened with the three-dimensional PCRbased method (Green and Olson, 1990).

Characterization of YAC clones. YAC clones identified by STSs underwent pulsed-field gel electrophoresis (PFGE) analysis by means of the PFGE set (Gene Line II, Beckman, USA). Electrophoresis was done on 1\% agarose gel at 350 $\mathrm{V}$ with pulse-time $120 \mathrm{sec}$ for $12 \mathrm{hr}$, at $370 \mathrm{~V}$ with pulse-time $240 \mathrm{sec}$ for $12 \mathrm{hr}$ and then at $390 \mathrm{~V}$ with pulse-time $360 \mathrm{sec}$ for $6 \mathrm{hr}$, all at $4^{\circ} \mathrm{C}$ in $0.25 \times \mathrm{TBE}$. After Southern hybridization at $65^{\circ} \mathrm{C}$ using high-molecule human Cot-1 DNA (GIBCO BRL, USA) as a pool of probe, membranes were washed at $65^{\circ} \mathrm{C}$ in $0.1 \times \mathrm{SSC} / 0.1 \%$ SDS. Total YAC DNA $(1 \mu \mathrm{g})$ was used for subsequent Alu-based PCR using primer 2484, $5^{\prime}$-aggagtgagccaccgcacccagccc-3' and primer PDJ34, $5^{\prime}$-tgagc(c/t)(g/a)$(\mathrm{a} / \mathrm{t}) \operatorname{gat}(\mathrm{c} / \mathrm{t})(\mathrm{g} / \mathrm{a})(\mathrm{c} / \mathrm{t})(\mathrm{g} / \mathrm{a}) \mathrm{cca}(\mathrm{c} / \mathrm{t})$ tgcactccagcctggg- $3^{\prime}$. PCR were cycled 30 times at $94^{\circ} \mathrm{C}$ for $1 \mathrm{~min}$ denaturation, at $55^{\circ} \mathrm{C}$ for $1 \mathrm{~min}$ annealing and at $72^{\circ} \mathrm{C}$ for $1.5 \mathrm{~min}$ extension. The 2484-PCR and PDJ34-PCR products were mixed and used for FISH analysis.

Furthermore, 7 sets of primers for published STSs located at a pericentromeric region of human chromosome 8 were used for another PCR study. The sequences $\left(3^{\prime}-5^{\prime}\right)$ of the primers were as follows: PLAT, $5^{\prime}$-tcagaagaggagccagatctta- $3^{\prime} / 5^{\prime}$-actctagatgtggacttagaga-3' (Sapru et al., 1994); D8S519, 5' -ctgcacccagcgtc-3'/5'-agtggcctttctgctcc-3' (Gyapay et al., 1994); D8S531, 5'-ttaggetggatgectgacctttta-3'/5'-gggaacattgtcactttcacgg-3' (Gyapay et al., 1994); D8S359, 5'-tggetgagaacagtggtagg-3'/ 5'-agaatggggtagttccttcac-3' (GDB ID: G00-215-519); D8S589, 5'-aacctccagaatggggatag- $3^{\prime} / 5^{\prime}$-acttttccagatagttactgtcaca-3' (GDB ID: G00-228-576); D8S538, 5'-agctgcttgtcattnactt-3'/5'-tactatttgtggcaattgtaatacc-3' (Gyapay et al., 1994); DNA-PK $3_{\mathrm{cs}}\left(3^{\prime}\right)$, $5^{\prime}$-ctgcagatagaaagcattacattg-3'/5'-tcttgatttaaactcatgctacga-3' (Blunt et al., 1995). PCRs were performed for $30-35$ cycles at $93^{\circ} \mathrm{C}$ for $1 \mathrm{~min}, 50-58^{\circ} \mathrm{C}$ for $1 \mathrm{~min}$ and $72^{\circ} \mathrm{C}$ for $2 \mathrm{~min}$, using DNA of SC3VA4, RD15/5 and three YACs as templates.

$P F G E$ analysis of $Y A C$ clones. Not $\mathrm{I}, M l u \mathrm{I}$ and $N r u \mathrm{I}$ were used for com- 
plete and partial digestions of agarose block DNAs from the three YACs, respectively. Digestion was done in $100 \mu 1$ reaction mixture according to the manufacturers' instruction. Gene Navigator system (Pharmacia, Sweden) were used for PFGE. Digested YAC DNA was electrophoresed in 1.2\% agarose gel with $180 \mathrm{~V}$, using the following 3 steps of pulse-time: $80 \mathrm{sec}$ for $12 \mathrm{hr}, 100 \mathrm{sec}$ for $6 \mathrm{hr}$ and 120 sec for $6 \mathrm{hr}$. After PFGE, agarose gel was soaked in $0.25 \mathrm{~N} \mathrm{HCl}$ for 5 min twice, then transferred to a nylon membrane (Hybond $\mathrm{N}+$, Amersham, UK). As probes, 2.7-kb and 1.7-kb products from pBR322 DNA digested with BamHI and PvuII were used for right and left arms of YAC. In addition, high molecular human Cot-1 DNA, the insert of DNA-PK ${ }_{\mathrm{cs}}$ clone 1, and PCR products with the primer DNA-PK $_{\mathrm{cs}}\left(3^{\prime}\right)$ were used for human contents of YACs, the $5^{\prime}$ region of the DNA-PK ${ }_{\mathrm{cs}}$ gene, and for the $3^{\prime}$-UTR of the gene (Blunt et al., 1995), respectively. These probes were radio-labeled by a random primer labeling kit (Amersham, UK) and hybridized at $65^{\circ} \mathrm{C}$ and washed at $65^{\circ} \mathrm{C}$ in $0.5 \times \mathrm{SSC}$.

\section{RESULTS}

Cosmid isolation and FISH analysis

The cosmid library constructed from RD15/5 contained $3 \times 10^{5}$ colonies. By colony hybridization, 379 clones with positive signals for human DNA were obtained, and all of them hybridized to human DNA by dot-blot hybridization. The other hybridization using total mouse DNA as a pool of probes revealed 34 negative and 345 positive clones. The 34 negative clones and 177 weakly-positive clones from the remainder underwent FISH analysis. Of a total of 211 clones analyzed by FISH, 18 gave fluorescence signals at 8q11 (Fig. 1a), 39 showed signals diversely at human chromosomes including chromosome 8 , and 154 gave no signal. Thus, at least 57 clones were supposed to contain mainly human DNA inserts and the remaining 154 were in part composed of human DNA.

\section{STSS from cosmid clones}

The 57 cosmid clones showing FISH signals at human chromosomes, some of them likely being identical, were subcloned into pUC19. Southern hybridization of the subcloned plasmids to total human DNA, DNA from a mouse-human hybrid cells containing a human chromosome 8 and that to total mouse DNA revealed that five plasmids had only human unique DNA sequences (data not shown), and each of these plasmids was derived from five different cosmid clones. After sequencing of DNA from the five plasmid clones, five oligonucleotide STS-primers were designed as shown in Table 1.

\section{Characterization of isolated $Y A C$ clones}

Using the STSs generated, five YAC clones were isolated from the CEPHYAC library (Table 2). PFGE analysis revealed that YAC clones (924b10, 923a12, 

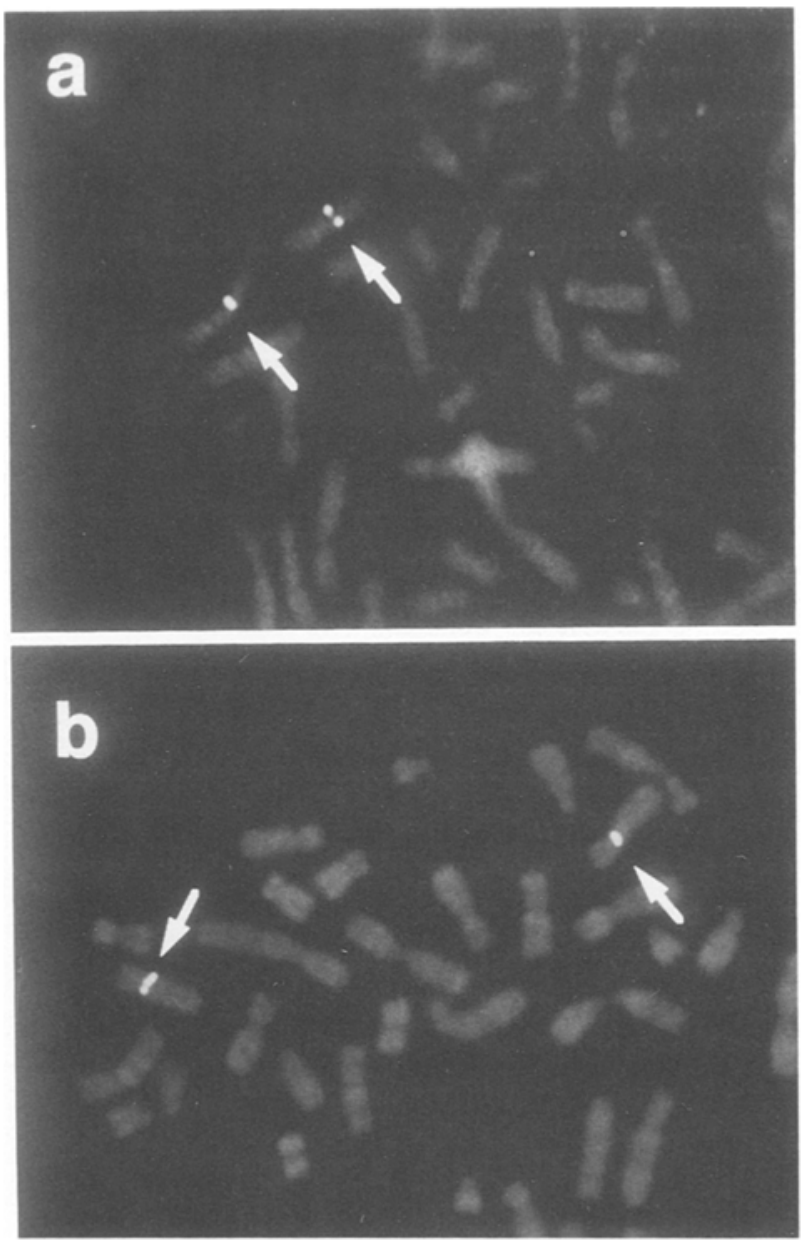

Fig. 1. Fluorescence in situ hybridization (FISH) analysis. Human metaphase chromosomes were hybridized with biotinylated DNA of a cosmid clone (RD15/ $5-\mathrm{Jl}$ ) constructed from inserted human DNA of RD15/5 (a), and with biotinylated DNA of $943 \mathrm{~g} 4-\mathrm{YAC}(\mathrm{b})$. Arrows show FISH signals at 8q11.

$943 \mathrm{~g} 4,911 \mathrm{f} 10$ and $822 \mathrm{~h} 3$ ) contained 1.1-Mb, 1.2-Mb, 1.7-Mb, 1.6-Mb and 1.7-Mb human DNA inserts, respectively. According to the CEPH-YAC data, 924b10 and 923a12 were judged to have deleted-human DNA inserts. Therefore, the other three YAC clones $(943 \mathrm{~g} 4,911 \mathrm{f} 10$ and $822 \mathrm{~h} 3$ ) were used for further analysis. FISH using YAC-derived Alu-PCR products as probes demonstrated that there was no evidence of chimerisim in these three human-DNA inserts, and mapped all these YACs to human chromosome 8q11 (Fig. 1b). Newly generated and previously published STSs information (Table 2) suggested that the three YAC clones overlapped each other. 
Table 1. STSs derived from human DNA inserted in RD15/5 cell line.

\begin{tabular}{|c|c|c|c|}
\hline Name of STS & Product size (bp) & $T_{\mathrm{a}}\left({ }^{\circ} \mathrm{C}\right)$ & Primer sequence \\
\hline \multirow[t]{2}{*}{ W143-4 } & 166 & 60 & TGGTGCTCCCAACTGCATCT \\
\hline & & & GCTCCTCTATTTCCTATTCC \\
\hline \multirow[t]{2}{*}{$\mathrm{J} 47-2$} & 177 & 60 & AGCAGACCCTGCAAGACAAG \\
\hline & & & ACAAGGAGCTTGGGCTAGAA \\
\hline \multirow[t]{2}{*}{ J4-9 } & 202 & 55 & ATGGCTCTCTGGCTGATGGA \\
\hline & & & CGACTTCTCTGCCCTATGCA \\
\hline \multirow[t]{2}{*}{ J110-10 } & 224 & 60 & СССАТСАССТTCATTTCAGG \\
\hline & & & ACAAGTAGTGGCAGGGACTA \\
\hline $\mathrm{J} 1-6$ & 156 & 60 & $\begin{array}{l}\text { CCTGCTATTCCAACACTCAT } \\
\text { AACTAGACTGCATCTTCAGG }\end{array}$ \\
\hline
\end{tabular}

$T_{\mathrm{a}}$, annealing temperature.

Table 2. Summary of STS study.

\begin{tabular}{|c|c|c|c|c|c|}
\hline \multirow{2}{*}{ STSs } & \multicolumn{3}{|c|}{ YAC clones } & \multicolumn{2}{|c|}{ Cell lines } \\
\hline & $943 \mathrm{~g} 4$ & $911 \mathrm{f} 10$ & $822 \mathrm{~h} 3$ & $\mathrm{RD} 15 / 5$ & SC3VA4 \\
\hline \multicolumn{6}{|c|}{ Present STSs } \\
\hline W143-4 & + & - & - & + & - \\
\hline $\mathrm{J} 47-2$ & + & - & - & + & - \\
\hline $4-9$ & + & + & + & + & - \\
\hline $\mathrm{J} 110-10$ & + & + & + & + & - \\
\hline $\mathrm{J} 1-6$ & - & - & + & + & - \\
\hline \multicolumn{6}{|c|}{ Published STSs } \\
\hline PLAT & - & - & - & - & - \\
\hline D8S519 & + & + & - & + & - \\
\hline D8S531 & + & + & - & + & - \\
\hline D8S359 & + & + & + & + & - \\
\hline D8S589 & - & - & - & - & - \\
\hline D8S538 & - & - & - & - & - \\
\hline DNA-PK & + & + & + & + & - \\
\hline
\end{tabular}

+ , positive; - , negative.

Restriction map of $Y A C S, Y A C$-contig and localization of the DNA-PK cs gene

The three YACs were aligned according to their restriction sites (Fig. 2). A YAC contig constructed encompassed about $2.7 \mathrm{Mb}$. The DNA-PK $\mathrm{cs}$ clone $1\left(5^{\prime}\right.$ region) was hybridized to $200-\mathrm{kb}$ Not $\mathrm{I}$-fragments of the three YACs, and its 3'-UTR PCR product was also hybridized to the same fragments (Fig. 3). These results indicated that the genomic region of the $\mathrm{DNA}-\mathrm{PK}_{\mathrm{cs}}$ gene spans less than $200 \mathrm{~kb}$. At each side of the fragment, a cluster of restriction sites was observed, indicating the possible presence of $\mathrm{CpG}$ islands flanking the gene.

\section{DISCUSSION}

We isolated a total of 379 cosmid clones containing human DNA, from a 


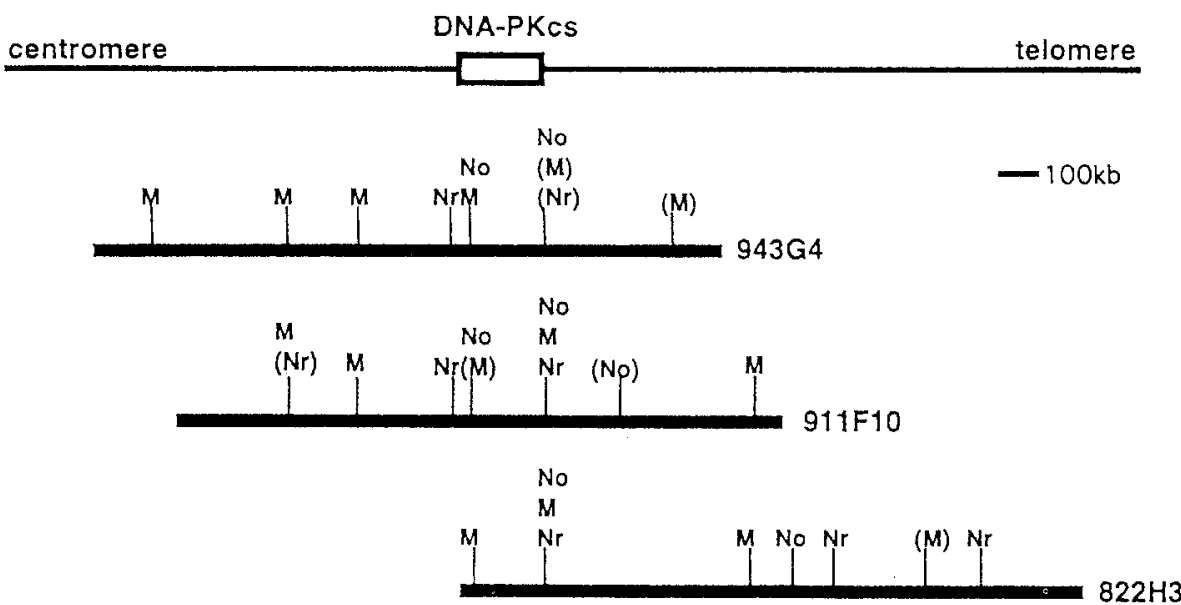

Fig. 2. Physical map of a YAC contig. Thick bars indicate YAC clones, and vertical lines restriction sites. No, $\mathrm{M}$ and $\mathrm{N}_{r}$ are $N o t \mathrm{I}, M l u \mathrm{I}$ and $N r u \mathrm{I}$, respectively.

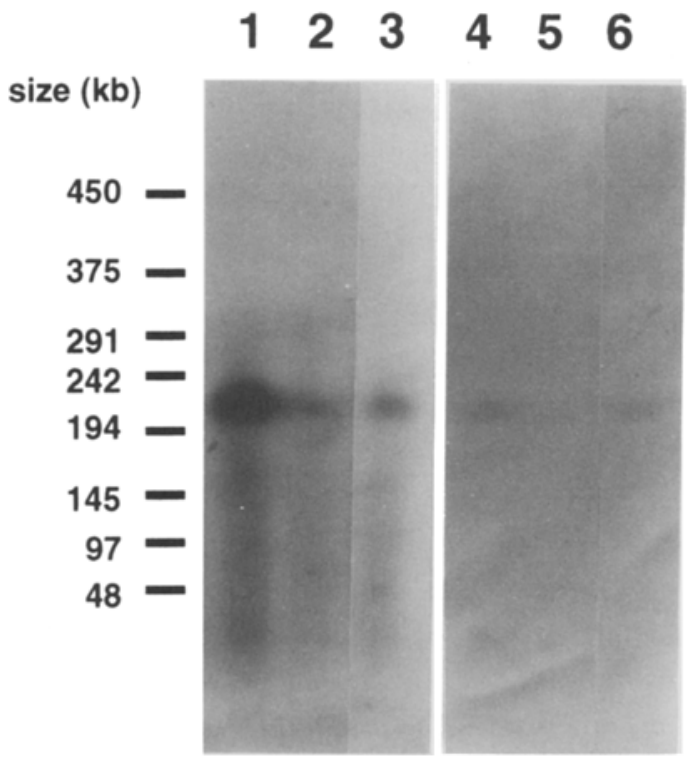

Fig. 3. Localization of the DNA-PK $\mathrm{cs}_{\mathrm{cs}}$ gene. Lanes 1-3 show Not I-digested YAC clones $(822 \mathrm{~h} 3,943 \mathrm{f} 4$ and $911 \mathrm{f10})$ hybridized with DNA-PK $\mathrm{cs}_{\text {clone }} 1$ (the $5^{\prime}$ region of the DNA-PK $\mathrm{cs}$ gene), lanes 4-6 the same YACs hybridized with the 3'-UTR PCR product, respectively. The former probe DNA on membrane was stripped and hybridized with the latter again.

library constructed from a human-scid mouse radiation cell hybrid which may contain HYRC. Three-steps of screening (colony hybridization, dot-blot hybridization and FISH) adopted in the present study demonstrated that 18 (4.7\%) of the 
379 clones contained human unique-DNA inserts. It is likely that a part of the remaining 361 clones were still composed of human DNA inserts, because some clones also gave FISH signals to human chromosome 8. Finally, five STSs and their corresponding three YACs overlapping each other were identified at the $8 \mathrm{q} 11$ region (Table 2).

A main goal of our study was to construct a contig of genetic clones at the $H Y R C$ region. In the present study, we adopted two different approaches: a bottom-up way from cosmid clones followed by STS construction and a subsequent top-down strategy from YACs. YACs still remain problematic, because they tend to become rearranged and chimeric, while rearrangements less frequently occur in cosmid clones. Since our STSs were acquired directly from the inserted human DNA in the complemented human-scid mouse hybrid cell line, they were useful for the isolation of a YAC that covers the $H Y R C$ locus. It was expected that a contig assembly starting from YACs followed by cosmid subcloning can be compared with the cosmid clones coming from a different source, and STSs will join them.

It has been confirmed that double-strand DNA breaks as well as V(D)J recombination in scid cell lines are restored by human $H Y R C$ region (Komatsu et al., 1995; Kirchgessner et al, 1995; Blunt et al., 1995), indicating that the HYRC locus encodes the scid factor that involves double strand DNA repair and all $\mathrm{V}(\mathrm{D}) \mathrm{J}$ recombination coding joint formation. A strong candidate gene for HYRC has been identified (Kirchgessner et al., 1995; Blunt et al., 1995; LeesMiller et al., 1995) and its partial cDNA has been cloned (Blunt et al., 1995). This gene encodes a huge $350-\mathrm{kDa}$ protein acting as a DNA-dependent protein kinase catalytic subunit $\left(\mathrm{DNA}-\mathrm{PK}_{\mathrm{cs}}\right.$ ). The expression of the $\mathrm{DNA}-\mathrm{PK}_{\mathrm{cs}}$ gene was observed in several cell types with a variety of doses, especially being highly expressed in Hela cell (Carter et al., 1990; Lees-Miller et al., 1990; Kirchgessner et al., 1995; Blunt et al., 1995). Analysis of gene expression in radiation sensitive or resistant tumor cells may develop new insights for radiation therapies. The DNA-PK $\mathrm{cs}_{\mathrm{cs}}$ gene is contained within a $280-\mathrm{kb}$ YAC clone (Blunt et al., 1995). Our study indicated that it spans $200 \mathrm{~kb}$. The physical map of our YAC-contig may be useful for the construction of a cosmid contig covering this huge gene as well as other genes of the region. Involvements of the $8 \mathrm{q} 11$-q 12 region in chromosome aberrations have been reported many times. They were often associated with various diseases, such as acute lymphoid leukemia (Testoni et al., 1993), malignant lymphoma (Huret et al., 1990), salivary gland pleomorphic adenoma and carcinoma (Bullerdiek et al., 1993; Jin et al., 1994), lymphoblastoma (Sawyer et al., 1994), Silver-Russell syndrome-like features (Schinzel et al., 1994) and another congenital anomaly (Walker and Bocian, 1987). There must be in this region some disease-related genes other than HYRC (Kirchgessner et al., 1995; Blunt et al., 1995; Lees-Miller et al., 1995) and C/EBPo (Cleutjens et al, 1993; Kirchgessner 
et al., 1995). Therefore, our physical map of YAC contig is also useful to isolate such genes.

Acknowledgments We express our gratitude to Professor Kenshi Komatsu at the Department of Radiation Biology, Research Institute for Radiation Biology and Medicine, Hiroshima University for providing the cell line, RD15/5, Dr. Yusuke Nakamura at the Laboratory of Molecular Medicine, Institute of Medical Science, the University of Tokyo for providing CEPH YACs and Dr. Stephan P. Jackson at the Wellcome/Cancer Research Campaign Institute and Department of Zoology, Cambridge University for providing DNA-PK ${ }_{c s}$ CDNA clones. Y.W. was supported in part by a Grant-in-Aid for Scientific Research (No. 06770612) and N.N. in part by Grants-in-Aid for Scientific Research (No. 06454609) from Scientific Research on Priority Areas (No. 06280226) and for Human Genome Program from the Ministry of Education, Science and Culture of Japan, and a Grant-in-Aid from the Ministry of Health and Welfare, Japan.

\section{REFERENCES}

Biedermann KA, Sun J, Giaccia AJ, Tosto LM, Brown JM (1991): scid mutation in mice confers hypersensitivity to ionizing radiation and a deficiency in DNA double-strand break repair. Proc Natl Acad Sci USA 88: 1394-1397

Blunt T, Finnie NJ, Taccioli GE, Smith GCM, Demengeot J, Gottlieb TM, Mizuta R, Varghese AJ, Alt FW, Jeggo PA, Jackson SP (1995): Defective DNA-dependent protein kinase activity is linked to V(D)J recombination and DNA repair defects associated with the murine scid mutation. Cell 80; 813-823

Bosma GC, Custer RP, Bosma MJ (1983): A severe combined immunodeficiency mutation in the mouse. Nature 301: 527-530

Bullerdiek J, Wobst G, Meyer-Bolte K, Chilla R, Haubrich J, Thode B, Bartnitzke S (1993): Cytogenetic subtyping of salivary gland pleomorphic adenomas: correlation to occurrence, histological subtype, and in vitro cellular behavior. Cancer Genet Cytogenet 65: 27-31

Carter T, Vancurova I, Sun I, Lou W, DeLeon S (1990): A DNA-activated protein kinase from HeLa cell nuclei. Mol Cell Biol 10: 6460-6471

Cleutjens CBJM, van Eekelen CCEM, van Dekken H, Smit EME, Hagemeijer A, Wagner MJ, Wells DE, Trapman J (1993): The human C/EBP $\delta$ (CRT3/CELF) gene: Structure and chromosomal localization. Genomics 16: $520-523$

Deng H-X, Yoshiura K, Dirks RW, Harada N, Hirota T, Tsukamoto K, Jinno Y, Niikawa N (1992): Chromosome-band-specific painting: chromosome in situ suppression hybridization using PCR products from a microdissected chromosome band as a probe pool. Hum Genet 89: $13-17$

Fulop GM, Phillips RA (1990): The scid mutation in mice causes a general defect in DNA repair. Nature 347: 479-482

Green ED, Olson MV (1990): Systemic screening of yeast artificial-chromosome libraries by use of the polymerase chain reaction. Proc Natl Acad Sci USA 87: 1213-1217

Gyapay G, Morissette J, Vignal A, Dib C, Fizames C, Millasseau P, Marc S, Bernardi G, Lathrop M, Weissenbach J (1994): The 1993-94 Genethon human genetic linkage map. Nature Genet 7: 246-339

Hendrickson EA, Qin XQ, Bump EA, Shatz DG, Oettinger M, Weaver DT (1991): A link between double-strand break-related repair and $\mathrm{V}(\mathrm{D}) \mathrm{J}$ recombination: The scid mutation. Proc Natl Acad Sci USA 88: 4061-4065

Huret JL, Brizard A, Babin P, Schoenwald M, Briault S, Guilhot F, Tanzer J (1990): Translocation $(8 ; 9)(\mathrm{q} 12 ; \mathrm{p} 21)$ : A new non-random rearrangement in lymphoid malignancies. Cancer

Vol. 41, No. 1, 1996 
Genet Cytogenet 45: 125-129

Jin Y, Mertens F, Limon J, Mandahl N, Wennerberg J, Dictor M, Heim S, Mitelman F (1994): Characteristic karyotypic features in lacrimal and salivary gland carcinomas. $\mathrm{Br} J$ Cancer $\mathbf{7 0}$ : 42-47

Kirchgessner CU, Patil CK, Evans JW, Cuomo CA, Fried LM, Carter T, Oettinger MA, Brown JM (1995): DNA-dependent kinase (p350) as a candidate gene for the murine SCID defect. Science 267: 1178-1183

Komatsu K, Ohta T, Jinno Y, Niikawa N, Okumura Y (1993): Functional complementation in mouse-human radiation hybrids assigns the putative murine scid gene to the pericentric region of human chromosome 8. Hum Mol Genet 2: 1031-1034

Komatsu K, Kubota N, Gallo M, Okumura Y, Lieber MR (1995): The scid factor on human chromosome 8 restores $\mathrm{V}(\mathrm{D}) \mathrm{J}$ recombination in addition to double-strand break repair. Cancer Res 55: 1774-1779

Lees-Miller SP, Chen YR, Anderson CW (1990): Human cells contain a DNA-activated protein kinase that phosphorylates simian virus $40 \mathrm{~T}$ antigen, mouse p53, and the human $\mathrm{Ku}$ autoantigen. Mol Cell Biol 10: 6472-6481

Lees-Miller SP, Godbout R, Chan DW, Weinfeld M, Day S III, Barron GM, Allalunis-Turner J (1995): Absence of p350 subunit of DNA-activated protein kinase from a radiosensitive human cell line. Science 267: 1183-1185

Lieber MR (1992): The mechanism of V(D)J recombination: A balance of diversity, specificity, and stability. Cell 70: 873-876

Sapru M, Gu J, Gu X, Smith D, Yu C-E, Yu C-E, Wells D (1994): A panel of radiation hybrids for human chromosome 8. Genomics 21: 208-216

Sawyer JR, Parsons EA, Crowson ML, Smith S, Erickson SS, Bell JM (1994): Potential diagnostic implications of breakpoints in the long arm of chromosome 8 in lipoblastoma. Cancer Genet Cytogenet 76: 39-42

Schinzel AA, Robinson WP, Binkert F, Fanconi F (1994): An interstitial deletion of proximal 8q (q11-q13) in a girl with Silver-Russell syndrome-like features. Clin Dysmorphol 3:63-69

Testoni N, Zaccaria A, Martinelli G, Pelliconi S, Buzzi M, Farabegoli P, Panzica G, Tura S (1993): $t(8 ; 14)(q 11 ; q 32)$ in acute lymphoid leukemia: Description of two cases. Cancer Genet Cytogenet 67: $55-58$

Walker AP, Bocian M (1987): Partial duplication 8q12-q21.2 in two sibs with maternally derived insertional and reciprocal translocations: Case reports and review of partial duplications of chromosome 8. Am J Med Genet 27: 3-22 